\title{
Effect of Financial Innovation on the Growth of Commercial Banks in Eldoret Town, Uasin Ishu County
}

\author{
Vivien Jebet Kiprop ${ }^{1,}$ Dr.Caroline Ayuma ${ }^{2,}$ Dr.Jared Bokongo ${ }^{3}$ \\ ${ }^{1}$ Department of Business, Faculty of Commerce,,KisiiUniversity, $P$ O Box 4016, post code 20100,Nakuru, Kenya, \\ ${ }^{2,3}$ Department of Business, Faculty of Commerce, Kisii University, P O Box 408 Kisii, Kenya,
}

\begin{abstract}
The study sought to assess the effect of financial innovation on the growth of financial institution in commercial banks in Eldoret town. The objective of the study was; to determine the effect of internet banking on growth of commercial banks, to determine the effect of M- banking innovation on growth of commercial banks, to examine the role Agency banking on growth of commercial banks and to determine the effect of Insurance on growth of commercial banks in Eldoret Town. The study was guided by the Silber's constraint theory of innovation, Kane's theory and Merton's market efficiency theory of innovation. The research adopted a descriptive research design. The target population consisted of 27 commercial banks in Eldoret town that are registered with Central Bank of Kenya. The target population was 648 respondents and 213 respondents were used as the sample size. The study used 5-point likert questionnaires as the method data collection instruments. Cronbach alpha was used to test reliability of the research instrument. The findings of the study indicated that all the predictor showed that there was statistical significant effect on the dependent variable growth of commercial bank. The study recommends that the management of commercial banks should ensure that they fully support internet banking policies by allocating enough resources to them in order to gain a competitive edge. It is further, recommended that the management at the banks should be dedicated to encourage customer training on the use of internet banking to enhance their capabilities. The banks should also recruit knowledgeable programmers to ensure efficiency in the internet banking services. The empirical study has indicated a number of relevant issues that the research project did not investigate, but which might be important for further research on financial innovations application to create a sustainable competitive advantage. This study was conducted in commercial banks in; other studies should involve other financial institutions in Kenya and explore the financial innovation strategies in order to obtain more holistic information.
\end{abstract}

Keywords: Internet Banking, M- banking innovation, Agency Banking,Insurance and Growth of Commercial Banks

\section{Introduction}

According to Tidd, Bessant and Pavitt (2011), financial innovation is considered to be a crucial requirement for the profitability and growth of organizations and other companies. One the way of achieving sustaining and growth performance is to encourage and promote creativity internally and financial innovative practices within the institution financial institution which provides financial products and payment services that enable financial firms to participate in the wider economy of any country. They offer credit/loan, risk management and savings products. Leelar (2006) explain that the important functions performed by commercial banks have remained reasonably constant over the past several years in spite of the reality that the industry structure has been through impressive transformation. Competition increases international competition, liberalized domestic regulation; growth in information technology and fast innovations in modern financial mechanisms has enabled this change. As a result of these transformations there is arising pressure to dramatically improve financial performance and productivity. Competition has created the financial industry to implement some of the financial innovative techniques in order to survive (Levich, 2008).

According to Davila et al (2006), financial innovation is the unexpected improvement in the collection of financial mechanisms and products that are encouraged by unanticipated transformation in tax policy, regulatory impulses, technology, preferences and needs of the customer. According to Merton (2006) financial innovation refers to the progress in technology which assists in trading, access to information, means of payment and to the appearance of new financial services and instruments, more developed new types of organization financial markets, and complete financial markets.

Globally, according to Desai and Low (2007), financial innovation has been for a particular period of time remained the main key to economic growth whether in any developing or developed country. For instance, there are a number of times of accelerated financial innovation in United States financial history, regularly following or all through periods of political disturbance and great social like the immense depression and Civil War. It seems clear in the year1970s and 1980s have been years of moderately rapid innovation due to higher inflation and its effects on rapid technological progress and interest rates that has drastically reduced the real costs of carrying out financial transactions. 
Lafour cade et al (2005) argues that in Sub-Saharan Africa financial institutions include a broad range of geographically dispersed institutions and diverse that offer financial services to rural banks, cooperatives, non-governmental organizations (NGOs), low income clients and non-financial institutions, and even financial institutions which are postal, savings and commercial banks growing in large numbers in Africa. Most financial institutions in Africa report low profits compared with other global regions due to communications and road(weak infrastructure), low average population density combined with high labor cost and predominantly rural markets all add to operating expenses. Given the ongoing developments in commercial banks in Uganda, Nigera, South Africa, there is considerable interest for many banks in Africa to keep pace with the changing financial innovational landscape in the industry. However, in most African countries, the financial industry has remained to a large degree underdeveloped due to poor financial innovation techniques (Gupta, 2008).

Some of the majority of financial innovations adopted by commercial banks in Kenya are the use debit cards and credit cards, which have also increased steadily from the late 1990s. This has ensured the issuance of e-money, which not only directly challenges the physical cash in payments made in small value but also deposits from bank through holding electronic money balances (Anderloni, Llewellyn and Schmidt, 2009). Other improvements in the banking sector include: the use of Cheques which accounts for $48 \%$ of non-cash payments (Gitonga, 2003). There is also the utilization of internet and mobile banking. According to Mwangi (2007), commercial bank Eazzy 247 is one such innovation that uses mobiles phones as their platform for financial services. It is a service of mobile banking that allows customers access bank services and products using their mobile phone. This reduces the amount of money that an individual can hold at hand at any particular time, thus affecting the demand for money. It is against this background that the study will evaluate financial innovation and how it affects the growth of financial institutions in UasinGishu County.

\subsection{Statement of the Problem}

Financial markets are becoming increasingly integrated and globalized, which has resulted in the demand for new types of investments. Ability to innovate and the financial innovation and its effects of have become the main element results in the threat of existent to deposit taking in financial institutions. Financial performance is significant to the growth of the organization. The international financial environment changes, the growing of financial markets which are international and amalgamation of domestic also lead to financial innovation. Locally, financial institutions like commercial bank have been forced to adapt to new financial innovations in order for them to handle the large sum of money they transact daily. They have continued to innovate and serve consumers better by introducing new products, new functions of financial institutions and call for transformations in the strategies of regulating agencies. In spite of all these innovations, the role of innovation on financial institution's growth has not been felt fully in the financial sector. This could be due inadequate understanding about the drivers of innovation and the slow testing of bank's performance (Mabrouk and Mamoghli, 2010).

\section{Literature Review}

\subsection{Effect of Internet Banking on Growth of Financial Institutions}

Internet banking is the use of telecommunication and internet networks to present a broad mixture of services and products that are of value to the bank customers (Steven, 2002) through the employ of a system that permits persons to perform banking activities at home or from their offices or over the internet. Some banks which online are traditional in nature and also offer online are banking, whereas other banks have no physical presence but are online only. Online banking all the way of applying the traditional banks permits customers to undertake transactions that are transactions that are routine, such as balance inquiries, stop-payment requests; account transfers, bill payments and most of them even offer loan applications which are online. Customers can access information that deal with their account information at any time, either day or night, and this can take place anywhere. Internet banking has improved the most banks efficiency in offering services to customers. Financial institutions in Kenya cannot do away with technological innovations such as information systems since they play a significant task in their daily operations because consumers are mindful of technological improvements and insist on higher service quality (Zewdia, 2013).

The revolution of information technology has affected almost every phase of existence, among them is the banking sector continuation. The electronic banking introduction has redefined and revolutionized ways banks are working. Technology is at present measured as the main contributor for their core competencies as well as the organizations' success. All the banks measured, observed that, better ability to transact with customers and reducing cost are some of the major drivers of great significance. Yaklef, (2001) identified reducing cost reduction is the main intrinsic benefit to banking. The desire to decrease both administrative and operational costs has forced banks to be in the electronic world. However, reducing costs is only attainable with customer adoption enhancement (Stewart,2003, Yaklef, 2001, Fin Cen, 2000).Internet banking is the application of telecommunication and internet networks to offer a variety of services and products that are of value to the 
bank customers. Internet banking includes transporting data into individual software used in accounting. Some online banking stages support aggregation of accounts to enable the customers to scrutinize all of their accounts and its information in one position even if they are with their main office of the bank or with other institutions. Banking in the course of internet use is taken as approving delivery direct for the services instead of a substitute for the banking branches. Internet has transformed the competition dimensions in the banking sector. Following the introduction of personal computer banking, phone banking and ATMs, which are the primary foundations of electronic finance, the improved penetration and acceptance of internet has supplemented a new delivery and distribution retail banking channel (Stewart, 2003)

Internet banking has added international acceptance as a new delivery channel for performing a variety of banking transactions. It gives the ability to the customer to undertake banking transactions at their convenient time. There are ways to offer internet banking and is through an existing bank with objective offices can assess a website and offer internet banking in addition to its traditional delivery channels. Secondly, a bank may be assessed as a branchless, which is virtual bank or internet-only (DeYoung,2001, Allen et al, 2002, Steven, 2002). Internet banking is called transactional online banking, because it entails facility provision such as fund transfer, buying financial services or products, online accessing accounts. The internet also helps financial institutions like banks to go through other financial markets without entailing their physical presence in those markets.

The prevalent accessibility of internet banking is anticipated to influence the combination of financial services formed by banks, the way in which banks create these services and the consequential bank's financial performances. This therefore is perceived by banks as a enhanced means to serve its ever growing and wide customer base with fast, efficient, quality, convenient manner and fast quality service. It is also understood to generate good returns to banks hence leading to profitability. Adding up, industry assess men outlining the possible influence of internet banking on risk profile and saving cost of the banks have also produced considerable interest and speculation about the influence of the internet on the sector of banking (Karjaluoto, Mattila and Pento,2001).

Online banking that involves traditional banks makes customers to undertake all transactions, like bill payments, stop-payment requests, account transfers, online loan applications and some even offer balance inquiries. Customers can get access to their account information and this can be done from any whereat any time. Internet banking has improved efficiency in banking in offering services to customers. Financial institutions in Kenya cannot dispose off technological improvement like information systems since they play an essential role in their daily activities because customers are keen of demanding higher quality services and technological advancements. Miklaszewska (1998) pointed out4 internet roles in a banking industry which is modern. First, it facilitates financial transactions between customer and the banks. Secondly, it gives financial institutions lasting access to financial information (Berger, 2003).

Third, the internet connects a bank's head office to its branches. Finally electronic banking enables customers verify their account information; transfer funds involving accounts pay bills, and perform other roles and functions. Customers have had way in to extra services like bond trading and online stock (Miklasewska, 1998).In Kenya a recent survey indicates that there is steady raise in use of e-banking technologies like mobile, automated teller machine (ATM), and online banking, credit card, electronic funds transfer and direct bill payments (CBK 2008). ATM banking is one of the widely and earliest used services in retail-banking in Kenya (Nyangosi et al. 2009).However, according to Central Bank of Kenya annual report, its usage and acceptance has been better by M-banking in the last years which are few (CBK 2008).

Currently, there are about eight million users of M-banking services compared four million people who hold accounts in conservative Kenyan financial institutions (CBK 2008). The great increase in number of people approving M-banking has been credited to accessibility and high number of mobile phone users. This is dependable with the consumer choice theory and demand conceptualized by Au and Kauffman (2008) in association to payments which are mobile. Based on their experience, customers can decide to accept a particular technology in banking such as mobile banking, seen to present such advantages as ease of use (Kolodinsky and Hogarth 2001).

Since the introduction of e-banking in Kenya, financial institutions have witnessed much transformation. Customers now have access to efficient, convenient and fast services in banking. They have realized that organizations that ignore preferences and needs of the customer in its development of a product will believe to fail (Agarwal et al. 2009). However while the rapid information communication technology development has made some banking responsibilities more cheaper and efficient, technological improvements have their reasonable share of problems. Gupta (2000),Aladwani (2001)and Hwanget al. (2003), cited that issues related to customer and internet security are the supreme challenges banking sectors face. This is true in Kenya since e-banking in Kenya is still increasing and growing thus the hub of most banks is on system setting up giving less concentration to the industry technical issues. Hence there is a necessity to handle risks associated and costs with internet banking. It is crucial that innovations in internet banking be made through costs and 
sound analysis of risks associated to evade harm on banks performance. The influence of internet-activities of banks on their growth continues to be unimportant irrespective of what is used as growth variable following industry norms and banking literature for bank growth definitions in Kenya. However the research on the adoption of internet banking by the customers has been huge, there has been very inadequate research on the effect of internet banking on the growth of financial institution especially within the Kenyan context.

$\mathrm{H}_{\mathrm{O} 1}$ : Internet Banking has no effect on growth of commercial banks in Eldoret Town

\subsection{Effect of M- Banking Innovation on Growth of Financial Institutions}

In the developing world and countries, financial institutions are employing mobile banking at a large extent to increase growth. The speed of transformations in the financial sector has speed up with more financial institutions accepting the possibility of using the mobile banking in their service delivery. Financial institutions and innovation are of fundamental significance to the economy as they encourage wealth creation and economic growth and (Barringer\& Ireland, 2008). The wireless industry is one of the most active and growing industry in the world economy today. There is a shift from the sitting and searching internet to roaming and receiving in mobile environment. In Kenya the usage of mobile phones has been unique with eighty percent of Kenyan population are now covered by mobile networks. Kenya has seen a wonderful increase in the number of phone subscriptions, from a cell phone subscription of twenty three thousand in 1995, 1,187,100 in 2002 which is $78.7 \%$, eleven million four hundred and forty thousand one hundred and ninety nine in 2007 which amount to $97.7 \%$ of whole subscriptions of telephone respectively. Mobile Phone services have enhanced the worth of a service or product in such a wonderful way. In general, mobile means real-time access and fully portable to the same information, tools and resources that, until current were accessible only from the desktop (Shanker, O' Driscoll, \&Reibstein, 2003). Recent developments in technology in mobile have allowed users to change their handsets from simple communication tools to more composite m-commerce gadgets.

KPMG International (2009) notes that mobile phones are being used as supreme options to personal computers and the confront is for the network operators to provide services that is trustworthy and has added value for the consumers. The growing gathering of use for mobile services to manufacturers of these devices, content providers, network operators, financial demand by consumers and services providers has used pressure on the industry (Karjaluoto, 2002). It consequently means that the mobile banking evolution is following the internet banking. Services in mobile banking enables other related devices, transfers between bank accounts, view account balances and settle bills. The customers are able to access online banking, at the same time receiving broad variety of banking operations (Alam, 2003).

There has been rapid growth in technological developments, which as a result has brought opportunities to institutions offering financial services and providing through use of channels that have numerous electronic options (Laukkanen\&Pasanen, 2007). Mobile phone is one such channel which providers in financial service use to serve their customers, those providers who have employed use of such channels have gained their growth in this direction thereby making cost savings and increasing numbers of their customers in the process. Due to increased competition, commercial banks have had to make the right options in the mix of what to employ of the processes together with which new development strategies to adopt to improve the investor's returns and sustain growth (Alam, 2003). Mobile banking applications are continuously being developed and have now become banks' optional channels for submission of banking services. According to Coelho (2003), one of the major techniques for a major focus for mobile network providers and growth the banking industry, is the mobile banking and the potential it offers in providing various services. For instance, the mobile banking applications would enable offering of real time two way data transmission, banking services, among other services (Daniel, 1999).

Services in mobile banking has allowed movement and facilitation of money from the banking institutions to the society in the urban and rural centres at transactions costs that are more cheaper than those accessible by commercial banks, which in the course has allowed the banks to reach the unbanked resulting in tremendous growth in the banking industry (Jenkins, 2008). The availability and easy access of mobile phone audits use and convenience in size has brought additional value and created opportunities to both customers, mobile service providers among others. Commercial banks are now able to reach many more new customers than before though at the same time provision to them with banking services at their convenience anywhere in the country, whereas new and existing customers are enjoying the affordability of the services and improved security and devices (Jenkins, 2008).

A member of the CGAP (2009) lately recognized administrative costs, such as transaction costs, as the main reason of high interest rates, mostly in disconnected markets and rural markets. Mobile banking presents a chance to decrease costs in transaction by replacing costly labor with less expensive, decreasing transportation costs associated with disbursing loans, collecting payments and automated technology (CGAP, 2009). A recent study by the Clinton Foundation estimates that mobile money may decrease transaction costs for financial institutions by up to 80 percent. By the end of 2010, Almost half 47.5 percent of all Kenyans own a phone (up 
from 26.9 percent in 2006), with the speed of ownership rising to 72.8 percent in eleven urban areas from fifty two percent in 2006 and 80.4 percent in Nairobi up from 63 percent in 2006 (Kenya FinancialSurvey, 2009). Further, 52 percent, in 2009 received money compared to 2006 was 16.5 percent. The major general money transfer means is M-PESA, is now used by 39.9 percent of all Kenyans and26 percent of all M-PESA users also save money on their phones. Over six users, store value in their phone for use while travelling; M-PESA is perceived as the slightest risky by 26.2 percent of respondents, least expensive 31.7 percent , fastest 64.3 percent, easiest to get 47.8 percent money transfer means (Kenya Financial Survey, 2009). The yearly payment transactions numbers rose to go beyond that of Western Union internationally and now reports for about 58 percent of the number of electronic payments in Kenya. The system allows users to sender withdraw money at over twenty three thousand outlets compared with approximately one thousand bank branches (CBK, 2010). The potential for reaching providers of services as savings, financial institutions and health insurance has expanded significantly since the emergence of Kenyan mobile banking (Jack \&Suri, 2010). In the introduction of mobile banking by most financial institutions, Safaricom, in particular obviously improved the number of subscribers from nine million subscribers in 2009 to twelve million subscribers in 2011.

The number of mobile transactions of financial institutions rose from 27\% in 2008 to 51\% in December 2011. This is because the M-PESA as the mobile service provider is the majoritywidely and popular networked services of mobile money (Financial Sector Deepening, 2011).Previous studies have shown the ability of technologies of mobile network for purpose of banking (Pousttchi, 2003; Taga and Karlson, 2004; Speed facts online Research, 2001). Most of this research are taken place in developed countries and hence may not imitate the effects on the growth and success of various organizational environments and especially the financial institutions in developing countries like Kenya. Various studies are conducted locally on financial institutions for instance Oriaro (2001) carried an assessment on the regulatory framework and its suitability for operations of financial institutions in Kenya.

Magiri (2002) investigated financial institutions credit models employed and its relationships in the attainment of outreach in Kenya. Ratemo (2004) carried a study on funded institutions expectations and strategy for development of financial institutions in SAID, Kenya and the. Ogindo (2006) conducted a study on an evaluation of performance of micro-financial institutions in Kenya. Wanjohi (2008) investigated positioning and competitive strategies within a changing organizational environment adopted by micro-financial institutions in Kenya. Mwindi (2002) studied them Is interest rates charged and its relationship of performance of micro and small enterprises in Nairobi. However, there are no existing studies that have been conducted to find out the effect of employing mobile banking on the growth of these financial institutions. This study will seek to fill this gap by investigating the effect of mobile banking on the growth of financial institutions.

$\mathrm{H}_{\mathrm{O} 2}$ : M- banking innovation has no effect on growth of commercial banks in Eldoret Town

\subsection{Role Agency Banking On Growth of Financial Institutions}

The Twenty First century has been featured by rapid growth and application of information technology, this entails modern ways of doing things, with the aim of improving productivity and cutting cost. The banking sector in Kenya as well as in most developing countries in the world changing to technology to transform on product development, delivery and its payment services, has embraced agency Banking. It is a new concept that lets banks to employ third parties so as to offer services and products on their behalf. Agency Bank is a postal outlet tight by operator of the mobile network and even the financial institution to produce client's transactions instead of a branch teller. It is the employee or owner of the retail outlet who lets its client deposit, pay their bills conducts the transaction, query about an account balance, withdraw and transfer funds, or even directing deposit from their employer receive government benefits. Banking agents can be lottery outlets, conveniences stores, supermarkets, post offices and pharmacies (Ivatury\& Layman, 2006).

The Agency Banking model was proposed in Kenya in May 2010, through the adjustment of the Chapter 488 Laws of Kenya of the Banking Act by and the Finance Act 2009,and Central Bank of Kenya (CBK) publication. The instruction of agency banking was meant to ensure institutions provide banking services cost effectively to customers. It is expected that the initiative will improve financial access for people who are lately under banked or unbanked (Central Bank of Kenya, 2011).Various scholars have conducted research in areas of Agency Banking, Wairi (2011) in her study factors influencing agency banking innovation of commercial banks in Kenya, and the study showed that the main indicators influencing agency banking usage among commercial banks in Kenya are Cost reduction, customer service enhancement and expanded presence by banks particularly in remote areas. The most important factor was cost reduction in the provision of banking services. Another main factor was the customer service enhancement prospect of owing to a greater level of expediency that comes with the availability of retail agent outlets. The study revealed that introducing third party retail agent presents several risk factors with regard to the effective regulation and supervision of banks, and therefore suggested that regulator harsh implements fulfillment with the agent banking procedures and directly observes the banking sector whereas the banks endlessly ensure vetting of agents is done careful. Wambugu, (2011), in 
the study factors influencing agency banking adoption by Commercial Bank in Kenya, found out that innovation were introduced in the period between 2006 and 2010.These included credit cards, ATMs, youth oriented accounts, internet banking, women oriented banking, children accounts, and now most lately introduced within the Kenyan banking sector agency Banking. The study revealed that $76.74 \%$ of the Commercial banks surveyed are locally owned thereby $51 \%$ or more of the shareholdings are domestic public owned.T his means that institutions that are locally owned are supporting entrepreneurships which is local hence a good convincing environment for Agency banking adoption. The study further revealed that 69.77 percent of the commercial banks surveyed have operated Agency Banking for a period between 9-12 months.

The research indicated that factors that influenced the adoption of Agency Banking included, increasing customer coverage, enhancing revenue, expanding customer base outside the existing branch network, high penetration of the of the unbanked and diverting customers from the crowded banking halls. This was inferred by the researcher to mean that, the major driving force for commercial banks while usage of Agency Banking is increasing revenues but at the same time reducing the operation cost. The challenges that the researcher indicated to be affecting the adoption of Agency Banking included fraud and money laundering, and fear of break into the premises of the agents. The researcher inferred that these findings to mean that the government regulation on fraud and money laundering ought to be more stringent to deter such vices and that the regulation on vetting of bank agent have worked positively thus making lack of trust with the bank agents the least of the challenges.

Ndome, (2011), in his study Adoption of Agent banking services among residents of Kawangware area in Nairobi, sought to determine the kind of services being utilized through agents banking channels and the factors that influence agent banking services adoptionby consumers. The study was employed through a descriptive research design. The study showed that accessibility to where the customers lived or worked as well as friendly service influenced the respondents in using the agent services. It further found out that both Point of Sale (POS) and Mobile phone channels were acceptable to customers. Clara Veniard of Melinda Gates foundation in the paper How Agent Banking changes the Economics of small Accounts, they identify one of the primary impediments to provide financial services to the poor through other bank-based channels and other branches being high cost inbuilt in the traditional banking techniques and methods. The amount of money exhausted by financial service providers to serve a poor customer with a carrying out small transactions and small balance and is purely too immense to enable such accounts workable. In addition, when the financial service contributors lack branches that are too close to the customer, the customer is will not transact and use their service. However, there is an emergence of latest delivery models as forms of radically changing the finances of banking to the poor.

By using retail points as cash merchants(agent banking) banks, telecom companies, and other providers can offer services in commercially viable way by decreasing fixed costs and persuade customers to often use the service, thereby providing access to extra revenue sources. The study found out that agency banking improves the economics of the institutions compared with branches, especially for high- transaction, low-balance accounts that are common among the poor user, low-balance accounts that are common among the poor users. Further finding is that agent banking system are costs are incurred only if transactions are realized, cheaper to operate than branches, , agent transaction platforms benefit from additional transactional resources, Agent banking works best for low balance ,High- transaction accounts (Veniard,2010).

$\mathrm{H}_{\mathrm{O} 3}$ : Agency Banking has no effect on growth of commercial banks in Eldoret Town

\subsection{Effect of Insurance on Growth of Financial Institutions}

Insurance is a highly specialized industry that offers greater security to the chances of among the whole society and common people. It is one of the financial institutions today that aids in organizational growth and economic development. Egeria (1996) describes insurance as commerce handmade which plays an important role in the going anxiety of humans as an economic animal. Chikeleze and Echekoba (2008), defined insurance as an agreement whereby the insurer, in return for a premium, agrees to pay the insured an amount of money or its corresponding in type during the occurrence of specified occasion that is different to the insured interest.

Insurance symbolizes a promise of future compensation that relate to specific losses in exchange for periodic payments. Insurance are familiar to capital markets and banks markets as they solve the need of private households and business units in financial intermediation. The only means out is to restructure the organization and organization to meet with the period demand, create more awareness about the training and retraining of staff, industry, gain maximization in the interest of the economy and wastage minimization.Insurance is bought in order to evade the possible risks of the future which may take place or may not take place. This is a form of economically ensuring that if such an incident takes place then the lost does not influence the current well-being of the property or people insured. Thus through insurance a person buys protection and security (Corolyne, 2011). 
Insurances are same to capital markets and banks as they serve the business units needs of private households in financial intermediation. The availability of insurance services is essential for the stable economy and can enable the business participants agree with the forced risks. By complying with alleges, insurance also has to form hold back funds and pool premiums. So insurance are playing an essential role by improving internal cash flow at the assurance and by creating large amount of assets placed on the capital market and hence may contribute to economic growth. The amount and complexity of the insurer' sties to other environment and institutions are equivalent to those of banks. Literature on insurance-growth, however, is not common and is mainly due to lack of sufficient data sources the importance of econometric analysis is weak (Leelar, 2006).

$\mathrm{H}_{\mathrm{O} 4}$ : Insurance has no effect on growth of commercial banks in Eldoret Town

\section{Materials And Methods}

The study employed a descriptive survey research design. The study targeted 648 respondents with a sample size of 213 respondents. The study used 5-point likert questionnaires as the method data collection instruments. The Cronbach's coefficient alpha was applied on the results obtained to determine how items correlate among them in the same instrument. Cronbach's coefficient Alpha of more than 0.7 was taken as the cut off value for being acceptable which enhanced the identification of the dispensable variables and deleted variables

\subsection{Data Analysis}

The study conducted initial data analysis using simple descriptive statistical measures such as, mean, standard deviation and variance to give glimpse of the general trend. However, correlation analysis was used to determine the nature of the relationship between variables at a generally accepted conventional significant level of $\mathrm{P}=0.05$ (Sekaran, 2003). In addition, multiple regression analysis was employed to test the hypotheses. Multiple regression analysis is applied to analyze the relationship between a single dependent variable and several independent variables (Hair et al., 2010). The beta ( $\beta$ ) coefficients for each independent variable generated from the model, was subjected to a $t$-test, in order to test each of the hypotheses under study. The regression model used to test is shown below:

$\mathbf{Y}=\square+\square_{1} \mathbf{X}_{1}+\square_{2} \mathbf{X}_{2}+\square_{3} \mathbf{X}_{3}+\square$

Where:-

$\mathrm{Y}=$. Growth of Financial Institution

$\beta=$ Constant.

$\beta_{1}, \beta_{2}, \& \beta_{3}=$ Regression Coefficients

$\varepsilon=$ Unexplained Variation i.e. error term, it represents all the factors that affect the dependent variable but are not included in the model either because they are not known or difficult to measure.

$\mathrm{X}_{1}$ is Internet Banking

$\mathrm{X}_{2}$ is $\mathrm{M}$ - banking innovation

$\mathrm{X}_{3}$ is Agency Banking

$\mathrm{X}_{4}$ is Insurance

All the above statistical tests were analyzed using the Statistical Package for Social Sciences (SPSS), version 20. All tests were two-tailed. Significant levels were measured at $95 \%$ confidence level with significant differences recorded at $\mathrm{p}<0.05$.

\subsection{Correlation results}

\section{Results And Discussion}

Pearson's measures the strength and direction of the linear relationship between variables. Pearson Correlations results in,From table 1.0 The variables were at $99 \%$ level of confidence, since 1 percent change in internet banking leads to $80.0 \%$ change in the growth of financial institutions. $1 \%$ change in M-banking leads to $87.1 \%$ change in the growth of financial institutions, $1 \%$ change in agency banking leads to $85.4 \%$ change in the growth of financial institutions and $1 \%$ change in insurance led to $90.3 \%$ change in the growth of financial institutions. From our finding it clearly indicated that insurance has high level of association and the growth of financial institutions as compared to other independent variable variables.

Table 1.0 Correlation

\begin{tabular}{|l|l|l|l|l|l|l|}
\hline \multicolumn{2}{|c|}{} & $\begin{array}{l}\text { Internet } \\
\text { Banking }\end{array}$ & M- banking & $\begin{array}{l}\text { Agency } \\
\text { Banking }\end{array}$ & Insurance & $\begin{array}{l}\text { Growth of financial } \\
\text { institutions }\end{array}$ \\
\hline \multirow{2}{*}{$\begin{array}{l}\text { Internet } \\
\text { Banking }\end{array}$} & Pearson Correlation & 1 & $.740^{* *}$ & $.754^{* *}$ & $.805^{* *}$ & $.800^{* * *}$ \\
\cline { 2 - 7 } & Sig. (2-tailed) & & .000 & .000 & .000 & .000 \\
\cline { 2 - 7 } & $\mathrm{N}$ & 201 & 201 & 201 & 201 & 201 \\
\hline \multirow{2}{*}{ M- banking } & Pearson Correlation & $.740^{* *}$ & 1 & $.856^{* *}$ & $.869^{* *}$ & $.871^{* *}$ \\
\cline { 2 - 7 } & Sig. (2-tailed) & .000 & & .000 & .000 & .000 \\
\hline
\end{tabular}


Effect of Financial Innovation on the Growth of Commercial Banks in Eldoret Town, Uasin Ishu

\begin{tabular}{|c|c|c|c|c|c|c|}
\hline & $\mathrm{N}$ & 201 & 201 & 201 & 201 & 201 \\
\hline \multirow{3}{*}{$\begin{array}{l}\text { Agency } \\
\text { Banking }\end{array}$} & Pearson Correlation & $.754^{* *}$ & $.856^{* *}$ & 1 & $.874^{* *}$ & $.854^{* *}$ \\
\hline & Sig. (2-tailed) & .000 & .000 & & .000 & .000 \\
\hline & $\mathrm{N}$ & 201 & 201 & 201 & 201 & 201 \\
\hline \multirow[t]{3}{*}{ Insurance } & Pearson Correlation & $.805^{* *}$ & $.869^{* *}$ & $.874^{* *}$ & 1 & $.903^{* *}$ \\
\hline & Sig. (2-tailed) & .000 & .000 & .000 & & .000 \\
\hline & $\mathrm{N}$ & 201 & 201 & 201 & 201 & 201 \\
\hline \multirow{3}{*}{$\begin{array}{l}\text { Growth of } \\
\text { financial } \\
\text { institutions }\end{array}$} & Pearson Correlation & $.800^{* *}$ & $.871^{\text {** }}$ & $.854^{* *}$ & $.903^{* *}$ & 1 \\
\hline & Sig. (2-tailed) & .000 & .000 & .000 & .000 & \\
\hline & $\mathrm{N}$ & 201 & 201 & 201 & 201 & 201 \\
\hline
\end{tabular}

\subsection{Model Summary}

From the results on model summary as shown in table $4.11, \mathrm{R}=0.927, \mathrm{R}$ - square $=0.859$, adjusted $\mathrm{R}$ square $=0.856$, and the $\mathrm{SE}=0.272$. Multiple correlation $\mathrm{R}$ coefficients indicate the degree of linear relationship of organization citizenship behavior with all the predictor variables, whereas the coefficient of multiple determinations R-square shows the provision of the total variation in the dependent variable growth of growth of financial institutions that is explained by the independent variables.The R-square gives us the coefficient of determination between the variables the results from the regression analysis give an R-square value of 0.859 , which means that $85.9 \%$ of the independent variables cause the change on dependent variable (growth of financial institutions).

Table 1.2 Model Summary

\begin{tabular}{|l|l|l|l|l|}
\hline Model & R & R Square & Adjusted R Square & Std. Error of the Estimate \\
\hline 1 & $.927^{\mathrm{a}}$ & .859 & .856 & .272 \\
\hline \multicolumn{2}{|l}{ a. Predictors: (Constant), Insurance, internet Banking, M- banking ,Agency Banking } \\
\hline
\end{tabular}

\subsection{Analysis of Variance (ANOVA)}

The significance of the regression model was tested using Analysis of Variance (ANOVA) whichprovides information about levels of variability within the regression ANOVA shows the importance of the relationship between the independent and the dependent variables

Table 1.3 ANOVA $^{\mathrm{a}}$

\begin{tabular}{|l|l|l|l|l|l|l|}
\hline Model & Sum of Squares & df & Mean Square & F & Sig. \\
\hline \multirow{3}{*}{1} & Regression & 88.353 & 4 & 22.088 & 299.068 & $.000^{\mathrm{b}}$ \\
\cline { 2 - 7 } & Residual & 14.476 & 196 & .074 & & \\
\cline { 2 - 7 } & Total & 102.829 & 200 & & & \\
\hline \multicolumn{2}{|l|}{ a. Dependent Variable: Growth of financial institutions } \\
\hline
\end{tabular}

The $\mathrm{F}$ test provides an overall test of significance of the fitted regression model. The $\mathrm{F}$ value of 299.068 with $\mathrm{p}$ value of 0.000 that is < than 0.005 , hence the model is significant. Therefore, it indicates that all the variables in the equation are important hence the overall regression is significant.

\subsection{Hypotheses Testing}

Hypothesis $1(\mathrm{Ho} 1) \mathrm{H}_{\mathrm{O} 1}$ :stated that there is statistical significant effect of Internet Banking on growth of commercial banks it revealed that coefficients of estimate which was significant basing on $\beta 1=0.161$ (p-value $=0.001$ which is less than $\alpha=0.05$ ) implying that we reject the null hypothesis and conclude that internet banking has positive and significant effect on growth of financial institutions. This indicates that increase inInternet Banking leads to an increase inon growth of commercial banks, i.e an increase in a given unit of internet Banking may contribute $16.1 \%$ on growth of commercial banks

Hypothesis $2\left(\mathrm{Ho}_{2}\right)$ stated that There is statistical significant effect of M. Banking ongrowth of commercial banks. Findings showed that Banking had coefficients of estimate which was significant basing on $\beta 2=0.273$ ( $\mathrm{p}$-value $=0.00$ which is less than $\alpha=0.05$ ) which implies that we reject the null hypothesis and argue Banking had positive and significant effect on growth of commercial banks that is in increase in a unit of Banking may contribute $27.3 \%$ ofongrowth of commercial banks.

Hypothesis 3 (Ho3) There is statistical significant effect of Agency Bankongrowth of commercial banks. Findings showed that agency banking had coefficients of estimate which was significant basing on $\beta 3=$ 0.0116 ( -value $=0.037$ which is less than $\alpha=0.05$ ) which indicates that we reject the null hypothesis and infer that agency bank has positive and significant effect on growth of commercial bank. This implies that the higher the agency bank the higher the growth of commercial bank that is in presence of agency bankcan contribute 
$11.6 \%$ of growth of commercial banks. Hypothesis 4 (Ho4) There is statistical significant effect of insurance ongrowth of commercial banks. Findings showed that insurance had coefficients of estimate which was significant basing on $\beta 3=0.374$ ( $p$-value $=0.000$ which is less than $\alpha=0.05$ ) which indicates that we reject the null hypothesis and infer that insurance has positive and significant effect on growth of commercial bank. This implies that the higher the agency bank the higher the growth of commercial bank that is in presence of insurancecan contribute $37.4 \%$ of growth of commercial banks.

\section{Table 1.4 Multiple Regression Model}

Table 1.4 Coefficients of internet banking, Agency banking, Insurance and Growth of financial institutions

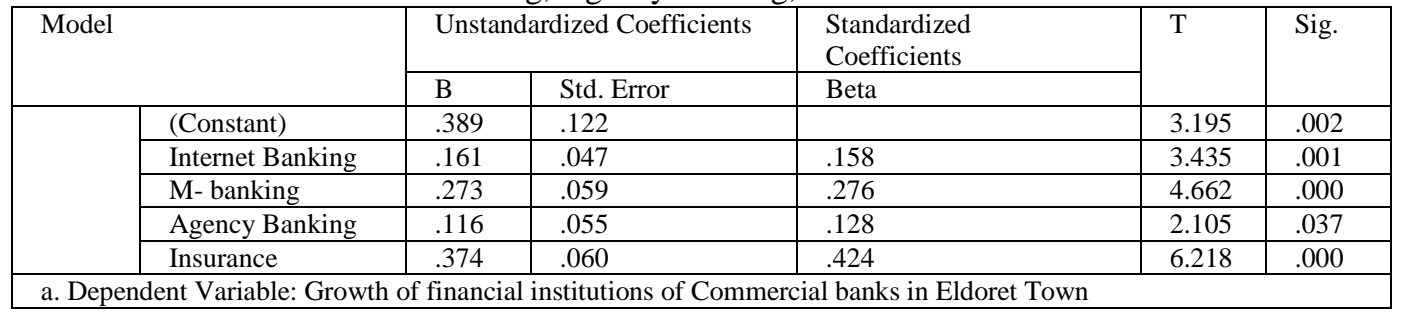

\section{Conclusion}

From the findings, the study concludes that the revolution of information technology has affected almost every phase of existence; among them is the banking sector continuation. The electronic banking introduction has redefined and revolutionized ways banks are working, on the effects of internet banking adoption among commercial banks in Eldoret town, it is concluded that by adopting internet banking services efficiency operation has been achieved, and also use of internet has led to the adoption of mobile money transfer which has contributed to reduction of operation cost. Further, increased numbers of adopting internet banking accounts have contributed to increase in revenue and the continuous usage of internet banking has reduced the cost of doing business. This is supported by the Silber's Constraint Theory of Innovation which is related to financial innovation and firm growth in that there are three possible ways a financial firm could make itself innovate by introducing an existing financial instrument from another country or industry into the firm's portfolio, indigenizing an exogenous item of the balance sheet, and as the mixture of the above two ways, taking the form of a modification of an existing instrument .Silber (1975), states that firms that are low in profitability in their respective sector are unreasonably innovative. Moreover, their decrease in profitability, which can be recognized to government regulation and external competition, has provided these firms with the necessary motivation to innovate in a bid to increase profitability hence enhancing growth.

On the effect of M- Banking Innovation on growth of financial institutions, it is concluded financial institutions and innovation are of fundamental significance to the economy as they encourage wealth creation and economic growth; the wireless industry is one of the most active and growing industry in the world economy today. There is a shift from the sitting and searching internet to roaming and receiving in mobile environment. Further the adoption of M-banking has not increased the bank's risk profile, Banks have written guidelines on security and convenience of mobile banking, also the use of m-banking has influenced the profitability of the bank and lastly M-banking has helped the banked enhance customer satisfaction. This is supported by merton's market efficiency theory of innovation, Merton argued that the market is not perfect hence financial institutions must innovate to improve market efficiency. According to Rene (2000) financial economists generally view funds flow to obtain advantage of opportunities in investment and financial innovations as positive forces that makes markets more efficient, facilitate risk sharing and increase growth. Merton (1990) gives three motivations for producing innovations namely, the creation of new financial structures that allow risk sharing, risk pooling and hedging as well as new financial structures for transferring resources, the improvement of economic efficiency and liquidity and reduction of agency costs.

Further on the role agency banking on growth of financial institutions, it is concluded that rapid growth and application of information technology, entails modern ways of doing things, with the aim of improving productivity and cutting cost, it is also concluded that Agency banking has improved customer services to prompt, it has minimized congestion of financial transaction in the banks, it improves the availability and accessibility of financial services and has made financial transaction quicker and reliable for all customers. This is supported by the Central Bank of Kenya (CBK) publication that the instruction of agency banking was meant to ensure institutions provide banking services cost effectively to customers. It is expected that the initiative will improve financial access for people who are lately under banked or unbanked. Further Wairi (2011) in her study factors influencing agency banking innovation of commercial banks in Kenya, and the study showed that the main indicators influencing agency banking usage among commercial banks in Kenya are Cost reduction, customer service enhancement and expanded presence by banks particularly in remote areas. 
Lastly on the effect of Insurance on growth of financial institutions, it is concluded that insurance has contributed to the banks market share and influences the image of the bank, also the availability of insurance in the bank has enhanced its profitability thus high level of customer referrals in relation to insurance. Further it is concluded that insurance symbolizes a promise of future compensation that relate to specific losses in exchange for periodic payments. Corolyne (2011) states that insurance are familiar to capital markets and banks markets as they solve the need of private households and business units in financial intermediation. Leelar (2006) the availability of insurance services is essential for the stable economy and can enable the business participants agree with the forced risks. By complying with challenges, insurance also has to form hold back funds and pool premiums. This further supported by Kane's market technology and political theory of innovation of (1984) which sees financial innovation as an institutional response to financial costs created by changes in technology, market needs, and political forces, particularly laws and regulations. Kane (1984) refers to the interactive process of regulation that follows institutional avoidance and innovations as dialectical process. Financial industry is exceptional it has stricter regulations and financial institutions have to tackle these regulations to reduce the potential risks to the minimum.

\subsection{Recommendation of the Study}

\subsubsection{Recommendation with Policy and Practice}

From the study findings and conclusions, the study recommends that the management of commercial banks should ensure that they fully support internet banking policies by allocating enough resources to them in order to gain a competitive edge. It is recommended that the management at the banks should be dedicated to encourage customer training on the use of internet banking to enhance their capabilities. The banks should also recruit knowledgeable programmers to ensure efficiency in the internet banking services. On the effects of Mbanking on growth of financial institutions, the study further recommends that there is need to improve on the efficiency of M-banking services to ensure that their customers are able to access online banking, at the same time receiving broad variety of banking operations Further on the role agency banking on growth of financial institutions, it is recommended that all the commercial banks should adopt the agency banking practice and enlighten their customers on its use, this will ensure increasing customer coverage, enhancing revenue, expanding customer base outside the existing branch network, high penetration of the of the unbanked and diverting customers from the crowded banking halls.Also it was concluded that commercial banks should develop superior product or customer support services. Any organization that has the capacity to quickly respond to customers need and provide subsequent support will have a competitive advantage over competitors. Lastly on the effects of insurance on growth of financial institutions should ensure that their customers are enlightened on the availability of insurance. The availability of insurance services is essential for the stable economy and can enable the business participants agree with the forced risks. By complying with challenges, insurance also has to form hold back funds and pool premiums. So insurance are playing an essential role by improving internal cash flow at the assurance and by creating large amount of assets placed on the capital market and hence may contribute to economic growth

\subsubsection{Suggestion for Further Research}

The analysis of the empirical study has indicated a number of relevant issues that the research project did not investigate, but which might be important for further research on financial innovations application to create a sustainable competitive advantage. This study was conducted in commercial banks; other studies should involve other financial institutions in Kenya and explore the financial innovation strategies in order to obtain more holistic information.

\section{References}

[1]. Abernathy, W. J. \& J.M., (1998). Patterns of Industrial Innovations, Technology Review, (80),

[2]. Ahmed, H. (2003). The role of Islamic financial institutions in financing micro- enterprises:theory and evidence. A paper presented at the Forum on Islamic and finance organised by the Arab Academy for banking and financial science in Amman, Jordan, 27-29 September, 2003

[3]. Ahmed, H. K.,Raza, A.,Amjad, W., \&Akram, M. (2011). Financial performance of Financecompanies in Pakistan.Interdisciplinary Journal of Contemporary Research in Business, 2(12), $732-744$

[4]. Ambler, T. \&Putoni, S. (2003). Measuring marketing performance, in Hart, S. (Ed), Marketingchanges, Thomson learning, London

[5]. Anderloni, L. Llewellyn, D.T. \& Schmidt, R. (2006, 2009).Financial Innovation in Retail and Corporate banking, Edward Elgar, UK 21(1), 47-48.

[6]. Batiz- Lazo, B. \& K, Woldesent, (2006). The dynamics of product and process innovation in UKbanking, International Journal of Financial Service Management 1(4), 400- 421

[7]. Berg, S. A., Forsund F.R \& Jansen, E. S (1992).Malquist indices of productivity growth duringthe deregulation of Norwegian banking, 1980- 1989, Scandinavian Journal of Economics, (9). $211-228$

[8]. Berger, A. N. \& Dick, A. A. (2006). 'Entry into banking markets and the first- mover advantage'The Journal of Money, Credit and Banking, 39 (4), $775-807$

[9]. Chew, D. H. (1997). Introduction: Financial Innovation in the 1980s and 1990s. The new corporate finance, McGraw- Hill Arwin44.75- 79

[10]. Cohen W. M. \&Levinthal, D.A (1989). Innovation and Learning: The two faces of R\&D,Economic Journal, (99).569- 596

[11]. Cohen, W. M. \&Levinthal, D.A (1990). Absorptive capacity: a new perspective on learning andinnovation, administrative science quarterly, (35). $128-54$ 
[12]. Corolyne, N., (2011). Financial Innovation and its effects on financial performance on thecommercial banks in Kenya, Unpublished MBA Project, University of Nairobi

[13]. Damanpour, F. \&Gopalakrishnan, S. (2001). The dynamic of the adoption of product andprocess innovation in organization, Journal of Management Studies, 38. 1, 45- 65

[14]. Damanpour, F. (1991). Organization Innovation: A Meta analysis of effects of determinants andmoderators, Academy of Management Journal, 34, 3,555-90

[15]. Davila, A. \& Shelton, R. (2006).Making Innovation Work, 9(2), 23-26

[16]. Dececco, M. (1987). Changing Money Financial Innovation in Developed countries, Brazil,Blackwel, Oxford

[17]. Desai, M. \& Low, M. (2007). Measuring the Opportunity for Product Innovation, in M.de Cecco(de.), Changing Money: Financial Innovation in Developed Countries[M]. Basil Blackwell, Oxford, 13(1), 229-230

[18]. Duade, Y. B. \&Akingbade, R. (2011). Equity and Bond Portfolio Analyst at Asset ManagementCorporation of Nigeria, Financial Service Industry, Lagos Nigeria

[19]. Frei, F. X., Harker, P. T. \& Hunter, L. W. (1998). Innovation in retail banking:working paper no.20 Warton financial institutions centre

[20]. Gitau, R.M (2011). The relationship between financial innovation and financial performance ofcommercial banks in Kenya. Unpublished MBA Project: University of Nairobi.

[21]. Gitonga, T. (2003).Innovation Processes \&The Perceived Role of The CEO In The BankingIndustry, Unpublished MBA Project, University of Nairobi.

[22]. Gupta, S. (2008). Microfinance in Africa: Harnessing the Potential of a Continent. MicrofinanceInsight. An Intellecap Publication. 2(2), 1-3.

[23]. Hicks, D. \&Niehans J. (1983). Financial Innovations, Multinational banking and monetarypolicy, Journal of Banking and Finance, 537- 55I

[24]. Ho, G \& Pennington. G. A (2006). The impact of local predatory lending laws on the flow ofsubprime credit, journal of urban economics, 60 (2), $210-228$

[25]. Humphery, D., Willessom, M., Bergendahl, G \&Lindblon, T. (2006). Benefits from a changingpayment technology in European banking, journal of banking and finance, 30, 6, 1631- 52

[26]. Hwang H, KU, C., Yen, D. C. \& Cheng, C. ( 2004). 'Critical factors influencing the adoption ofdata warehouse technology' a study of banking industry in Taiwan; Decision Support System, 37, 1, 1- 21

[27]. Jacobson, R. (1988). 'The persistence of abnormal returns' strategic management journal,9,5,415- 430

[28]. Jose L, A. (1999). Using CAMELS rating to monitor bank condition, FRBSF economic letter 99-119

[29]. Joseph, A. \& Mark, K. (2003), Service quality in the banking sector: the impact of technology onservice delivery. International Journal of Bank Marketing, 17, 4, 182-91.

[30]. Joshua, A. (2005). 'The effects of Capital Structure on profitability: an empirical analysis oflisted firms in Ghana: Journal of Risks Finance, (6).

[31]. Kane, F. (1987). The theory of Financial Innovation: 'A new Approach' Research Papers inBanking Finance

[32]. Lafourcade, L. (2005). Overview of the Outreach and Financial Performance of Microfinance Institutions in Africa. ISBN 0-13-149786-3

[33]. Leelar, D.T. (2006). Financial innovation: A Basic Analysis in Financial Innovation, Routledge,,Routledge,UK. 3(1), 48-53

[34]. Leonard, D \& Swap, W., (1999). When Sparks fly: Igniting creativity in groups.HarvardBusiness School Press, Boston, Massachusetts

[35]. Levich, R. M. (2008). Financial Innovations in International Financial Markets: The Changing Role of the United States and the World Economy. UCP, Chicago

[36]. Merton, R.C. (2006). Financial Innovation and Economic Performance, Journal of AppliedCorporate Finance, 4(4), $23-24$.

[37]. Miles, R. E. \& Snow, C. C. (1978). Organizational strategy structure and process, McGraw-Hill,New York, NY 46

[38]. Muthoni, M. G. (2013). The effect of financial innovation of financial performance of insurancecompanies in Kenya.Unpublished MBA Project, University of Nairobi

[39]. Mwangi, M. K. (2007). Factors Influencing Financial Innovation in Kenya"s Securities Market: A Case Study of Firms Listed at The Nairobi Securities Exchange. Unpublished MBA Project, University of Nairobi.

[40]. Ngari, J. M., \&Muiruri, J. K., (2014). Effects of financial innovation on the financialperformance of commercial banks in Kenya, International Journal of Humanities \& Social Sciences, 4 (7), 10- 13

[41]. Noyer, C., (2007).Financial Innovation, Monetary Policy and Financial Stability. SpringConference, Banque de France.

[42]. Nyangosi, R. (2008), E- banking: an integration technology in Kenya. The African executive publication, finance and banking.

[43]. Richard, O., Mcmillan, A., Chadwick, K. \& Dwyer, S. (2003), 'employing and innovation strategy in racially diverse workforce: effects on firm performance' Group and Organization Management, 28 (1), 107- 126

[44]. Roberts, P.W. \&Amit, R. (2003), 'the dynamic of innovative activity and competitive advantage: the case of Australian retail banking, 1981, to 1995, organization science, 14, 107- 122

[45]. Rogers, E. M. (2003). Diffusion of innovation, 5th ed., Simon and Schuster, New York, NY

[46]. Rogers, S. (1994). Performance management in local Government, Longmans, Harlow

[47]. Rycroft, R.W. \&Kash, D.E. (1999). "Managing Complex Networks: keys to 21st Century Innovation Success", Research and Technology Management, 42 (3), 13-18

[48]. Schumpeter, J., (1934). 'Theory of Economic Development 'translated by Reveres OpieCambridge Mass: Harvard University Press

[49]. Silber, W. L (1983). The process of Financial Innovation.American Economic Review, vol (73), May

[50]. Smith, A. (1999). quality aspects of services marketing, marketing intelligence \& planning, 8,25-32

[51]. Stigler, J. E (1994) 'The Role of the state in financial markets, in proceedings of the World BankAnnual Conference of Development1993, Washington D.C: World Bank, 19- 52

[52]. Sylla, R. (1982) Monetary Innovation in America. Journal of Economic History, 42, 1, 21 - 30

[53]. The American Heritage Dictionary, (2000). The American Heritage Dictionary of the EnglishLanguage, 4th edition, Houghton Mifflin Company, United States

[54]. Tidd, J., Bessant, J. \&Pavitt, K. (2011). Managing Innovation: Integrating Technology, Market and Organization Change.

[55]. Tidd, J.,Besant, J. \&Pavitt, K.(2001). Managing Innovation; integrating technology, market andorganizational change, 2nd edition, John Wiley \& Sons Ltd. Westsussex, England

[56]. Zaltman, G., Duncan, R \&Holbek, J. (1973).Innovations and organizations, John Wiley, NewYork, NY.48

[57]. Zewdia, G.H. (2013). The Effects of Financial Innovation on the Financial Performance ofListed Commercial Banks in Kenya,Unpublished MBA Projects, University of Nairobi. 